\title{
Expression of P-glycoprotein, multidrug resistance-associated protein, glutathione-S-transferase pi and p53 in canine transmissible venereal tumor ${ }^{1}$
}

\author{
Daniel G. Gerardi ${ }^{2 *}$, Mirela Tinucci-Costa ${ }^{3}$, Ana Carolina T. Silveira ${ }^{4}$ \\ and Juliana V. Moro ${ }^{3}$
}

\begin{abstract}
Gerardi D.G., Tinucci-Costa M., Silveira A.C.T. \& Moro J.V. 2014. Expression of P-glycoprotein, multidrug resistance-associated protein, glutathione-S-transferase pi and p53 in canine transmissible venereal tumor. Pesquisa Veterinária Brasileira 34(1):71-78. Departamento de Medicina Animal, Faculdade de Veterinária, Universidade Federal do Rio Grande do Sul, Av. Bento Gonçalves 9090, Porto Alegre, RS 91540-000, Brazil. E-mail: daniel.gerardi@ufrgs.br

The overexpression of proteins P-glycoprotein (P-gp), multidrug resistance-associated protein (MRP1), mutant p53, and the enzyme glutathione-S-transferase (GSTpi) are related to resistance to chemotherapy in neoplasms. This study evaluated the expression of these markers by immunohistochemistry in two groups of canine TVT, without history of prior chemotherapy (TVT1, n=9) and in TVTs presented unsatisfactory clinical response to vincristine sulfate (TVT2, $n=5$ ). The percentage of specimens positively stained for P-gp, MRP1, GSTpi and p53 were, respectively $88.8 \%, 0 \%, 44.5 \%$ and $22.2 \%$ in TVT1 and $80 \%$, $0 \%, 80 \%$ and $0 \%$ in TVT2. In TVT1, one specimen presented positive expression for three markers and four specimens for two markers. In TVT2, three specimens expressed P-gp and GSTpi. In conclusion, the canine TVTs studied expressed the four markers evaluated, but just P-gp and GSTpi were significantly expressed, mainly at cytoplasm and cytoplasm and nuclei, respectively, either before chemotherapy as after vincristine sulfate exposure. Future studies are needed to demonstrate the function of these two markers in conferring multidrug resistance (MDR) or predict the response to chemotherapy in canine TVT.
\end{abstract}

INDEX TERMS: Transmissible venereal tumor, P-glycoprotein, multidrug resistance, immunohistochemistry, neoplasm, dogs.

RESUMO.- [Expressão da glicoproteína-P, proteína associada à múltiplas drogas, glutationa-S-transferase pi e p53 no tumor venéreo transmissível canino.] A superexpressão das proteínas glicoproteína-P (Gp-P), proteína associada à resistência à múltiplas drogas 1 (MRP1) e p53

\footnotetext{
${ }^{1}$ Received on April 12, 2013.

Accepted for publication on November 19, 2013.

${ }^{2}$ Departamento de Medicina Animal, Faculdade de Veterinária, Universidade Federal do Rio Grande do Sul (UFRGS), Av. Bento Gonçalves 9090, Porto Alegre, RS 95320-000, Brazil. *Corresponding author: daniel.gerardi@ufrgs.br

${ }^{3}$ Departamento de Clínica e Cirurgia Veterinária, Faculdade de Ciências Agrárias e Veterinárias, Universidade Estadual Paulista (Unesp), Campus Jaboticabal. Via de acesso Paulo Donatto Castellane s/n, Jaboticabal, SP 14884-900, Brazil. E-mail: mirelatc@fcav.unesp.br

${ }^{4}$ Núcleo de Medicina Veterinária, Universidade Federal de Sergipe, Rua Maye Bell Taylor 150, apto 1101, Bairro Luzia, Aracaju, SE 49045-030, Brazil. E-mail: actrompieri@yahoo.com.br
}

mutante e a enzima glutationa-S-transferase pi (GSTpi) está relacionada com resistência à quimioterapia em neoplasias humanas e caninas. Este estudo avaliou a expressão, por meio da imuno-histoquímica desses marcadores em espécimes de TVT caninos sem histórico de quimioterapia prévia (TVT1, n=9) e em TVT caninos que apresentaram resposta clínica insatisfatória ao sulfato de vincristina (TVT2, n=5). A porcentagem de espécimes positivos para Gp-P, MRP1, GSTpi e p53 foram, respectivamente 88,8\%, 0\%, 44,5\% e $22,2 \%$ no grupo TVT1 e $80 \%, 0 \%, 80 \%$ e $0 \%$ no grupo TVT2. No TVT1, um espécime apresentou expressão positiva para três marcadores e quatro para dois marcadores. No TVT2, três espécimes expressaram a Gp-P e GSTpi. Em conclusão, os TVTs caninos estudados expressaram os quatro marcadores avaliados, no entanto apenas a Gp-P e GSTpi foram significativamente expressas, principalmente no citoplasmas e no citoplasma e no núcleo, respectivamente, 
tanto antes da quimioterapia quanto após à exposição ao sulfato de vincristina. Estudos futuros são necessários para demonstrar a função desses dois marcadores em conferir resistência à multiplas drogas (RMD) ou predizer a resposta a quimioterapia no TVT canino.

TERMOS DE INDEXAÇÃO: Tumor venéreo transmissível, Glicoproteína-P, Resistência à múltiplas drogas, imuno-histoquímica, neoplasias, caninos.

\section{INTRODUCTION}

Canine transmissible venereal tumor (TVT) is a contagious tumor transmitted experimentally or naturally during coitus. The TVT cells may spread on the mucosal surface of the external genital organs of male and female dogs and other anatomical spots contaminated by licking or by direct contact to the tumor (Cohen 1985, Knapp et al. 2000, MacEwen 2001).

The most efficient treatment for TVT is chemotherapy (Knapp et al. 2000, MacEwen 2001, Tinucci-Costa 2009). Some of the chemotherapic agents most commonly used are vincristine, cyclophosphamide, and doxorubicin (MacEwen 2001) though vincristine sulfate shows greater effectiveness (Calvert et al. 1982). Although cure is expected in over $90 \%$ of treated animals, resistance to treatment may be observed (Calvert, et al. 1982, Knapp et al. 2000, Brandão et al. 2002). However, the mechanism involved in chemoresistance to election drugs for the treatment of canine TVT is yet to be discovered.

In many human neoplasms and in some in veterinary medicine, the failure of chemotherapy is attributed mainly to the mechanisms of multidrug resistance (MDR) (Di Pietro et al. 1999, Bergman 2003). This phenomenon is characterized by tumor cells selected to resist to a single chemotherapy agent presenting cross resistance to several other compounds unrelated structurally or functionally (Thomas \& Coley 2003). Drug resistance may be related to intrinsic cell mechanisms, when cells are resistant prior to the beginning of therapy, or may be acquired, evolving after exposure to chemotherapy (Bergman 2003, Thomas \& Coley 2003).

Cell mechanisms of MDR include activation of transmembrane proteins that reduce intracellular concentrations of different chemical compounds; activation of the glutathione/glutathione-S-transferase system; alterations in drug target; mechanisms of repair; modifications in genes and proteins involved in apoptosis control (Bergman 2003, Munoz et al. 2007). Among the mechanisms of MDR, the overexpression of glycoprotein-P (P-gp) is the most studied and best characterized. P-gp acts as an ATP dependent efflux pump, actively expelling drugs from the cytoplasm of neoplastic cells, thereby limiting their cytotoxic effect (Di Pietro et al. 1999).

A second type of protein of the same family of P-gp discovered in 1992 was found to act as an efflux pump in cells isolated from small cell lung carcinoma resistant to doxorubicin. This protein denominated multidrug resistance-associated protein (MRP) is the second most frequent mechanism of MDR (Cole et al. 1992).
Another protein that could be involved in drug resistance in neoplastic cells is glutathione-S-transferase pi (GSTpi), a member of glutathione-S-transferases (GSTs) family, which catalyzes highly reactive hydrofilic intermediates into glutathione conjugates (GSH), less reactive and more easily excreted from the cells. An increase in GSTpi expression has been reported in cell lineages resistant to alkylating agents, in particular cyclophosphamide (Townsend \& Tew 2003).

The gene $p 53$ and the genes it regulates are critical elements in stress response, including antitumor drugs influenced reactions. The normal protein cascade triggered by $\mathrm{p} 53$ in response to different cell lesions either results in a blockage of the cell cycle or apoptosis. Thus, damaged cell is either eliminated or has its DNA repaired. Mutations in gene $p 53$ are very frequent in tumors and these alterations result in the prevention of its normal activity. Cells become unable to die by apoptosis or to interrupt its cell cycle and repair the DNA damage. Thus, alterations in p53 function may result in changes in tumor cells sensitivity to drugs, leading to resistance to antineoplastic drug, therefore interfering with apoptosis (Konstantinidou et al. 2002).

The aim of this study was to (1) verify whether canine TVT cells expressed the proteins related to MDR, namely the P-glycoprotein, the multidrug resistance-associated protein 1, the glutathione-S-transferase isoenzyme pi and the mutant p53; (2) define the immunostaining pattern of these proteins in canine TVT cells; and (3) verify whether differences existed between the number of canine TVT positives for the four markers prior to chemotherapy and TVT that presented unsatisfactory clinical response to the chemotherapy protocol with vincristine sulfate.

\section{MATERIALS AND METHODS}

Specimens. Fourteen specimens of TVT in paraffin blocks were selected from the archives of the Laboratory of Immunohistochemistry of São Paulo State University (UNESP). All the specimens belonged to dogs examined at the Veterinary Teaching Hospital of the same institution, and were collected in biopsy incisions, with diagnosis confirmed by histopathological examination. All the information, such as breed, age, gender, tumor location, administered drugs, and treatment response have been collected from the medical records of the patient.

The specimens were enrolled into two distinct groups: TVT1 ( $\mathrm{n}=9$ ), comprising specimens belonging to dogs with no history of antineoplastic treatment or any other drugs; and TVT2 $(n=5)$, comprising specimens that presented unsatisfactory clinical response to the chemotherapy protocol with vincristine sulfate according to Lorimier and Fan (2007). This study has been approved by the Animal Research Ethics Committee of the São Paulo State University at Jaboticabal, São Paulo, Brazil, under the protocol number 002140/11.

Immunohistochemistry. The method used was the Streptavidin-Biotin-Complex. Four primary antibodies were employed to evaluate the expression of proteins P-gp, MRP1, mutant p53, and isoenzyme GSTpi in the two experimental groups (Table 1).

Three micrometers samples were arranged in histological slides previously treated with poly-L-lisine (Code P4832 - Sigma Chemical Co., St Louis, MO, USA). Peroxidase endogenous activity was blocked immersing the slides in a $8 \%$ hydrogen peroxide me- 
Table 1. Antibodies specifications used in immunohistochemistry reactions

\begin{tabular}{|c|c|c|c|c|c|}
\hline $\begin{array}{l}\text { Primary } \\
\text { antibodies }\end{array}$ & $\begin{array}{l}\text { Immunoglobulin } \\
\text { (subclass) }\end{array}$ & Specificity & Clone & Dilution & Code \\
\hline P-gp & $\operatorname{IgG} 2 \mathrm{a}$ & Mouse anti-human & $\begin{array}{l}\text { Monoclonal } \\
\text { C494 }\end{array}$ & $1: 200$ & $8710-01 a$ \\
\hline MRP1 & $\operatorname{IgG} 2 \mathrm{a}$ & Mouse anti-human & $\begin{array}{l}\text { Monoclonal } \\
\text { 33A6 }\end{array}$ & $1: 25$ & NCL-MRP1b \\
\hline $\begin{array}{l}\text { GSTpi } \\
\text { p53 }\end{array}$ & - & $\begin{array}{l}\text { Rabbit anti-human } \\
\text { Rabbit anti-human }\end{array}$ & $\begin{array}{l}\text { Polyclonal } \\
\text { Ab-1 } \\
\text { Polyclonal }\end{array}$ & $1: 50$ & RB-050-A0c \\
\hline & & & CM1 & $1: 100$ & NCL-p53-CM1b \\
\hline
\end{tabular}

thanol solution for 20 minutes (except for the anti-MRP1 antibody reactions). The antigen retrieval was conducted through heat and the technique was chosen according to the primary antibody used (Table 2). After cooling the slices for 20 minutes at room temperature, the non-specific background reactions were blocked. The slices were then incubated overnight (12-18 hours) with the primary antibody at $4^{\circ} \mathrm{C}$. The slices were incubated with a biotinilated secondary antibody (Table 2), following incubation with the Streptavidin-Biotin-peroxidase (Vectastain ABC Elite Kit, Vector Laboratories, CA, EUA or Easypath kit, EP-USA, Erviegas instrumental cirúrgico, São Paulo, Brazil). The reactions were revealed by the chromogenic substrate 3.3 diaminobenzendine (DAB Vector Laboratories, Burlingame, CA, EUA) and counterstained with Harris hematoxylin for one minute.

Table 2. Primary antibodies and their respective methods and antigen retrieval solution, blockade of non-immune links and secondary antibodies used in immunohistochemistry reactions in this study, by $A B C$ method

\begin{tabular}{|c|c|c|c|}
\hline $\begin{array}{l}\text { Primary } \\
\text { antibody }\end{array}$ & $\begin{array}{l}\text { Retrieval } \\
\text { solution }\end{array}$ & Method & $\begin{array}{l}\text { Blockade of non- } \\
\text { immune links }\end{array}$ \\
\hline P-gp & Retrieve-all $1^{\mathrm{a}}$ & $\begin{array}{l}\text { Double boiler } \\
\text { (30 minutes) }\end{array}$ & $\begin{array}{l}\text { Normal horse serum }^{\mathrm{b}} \\
20 \text { minutes }\end{array}$ \\
\hline MRP1 & $\begin{array}{c}\text { Tris-EDTA } \\
\mathrm{pH}=9.0\end{array}$ & $\begin{array}{l}\text { Pressure cooker } \\
\quad(5 \text { minutes })\end{array}$ & $\begin{array}{l}\text { Normal horse serum }^{\mathrm{b}} \\
20 \text { minutes }\end{array}$ \\
\hline GSTpi & Retrieve-all $1^{\mathrm{a}}$ & $\begin{array}{l}\text { Double boiler } \\
\text { (30 minutes) }\end{array}$ & $\begin{array}{l}\text { Normal goat serum }{ }^{c} \\
\quad 20 \text { minutes }\end{array}$ \\
\hline p53 & $\begin{array}{l}\text { Citrate } \\
\mathrm{pH}=6.0\end{array}$ & $\begin{array}{l}\text { Pressure cooker } \\
\text { (5 minutes })\end{array}$ & $\begin{array}{c}\text { Bovine serum albumin }{ }^{\mathrm{d}} \\
\text { overnight }\end{array}$ \\
\hline
\end{tabular}

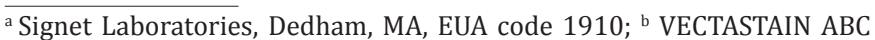
Elite Kit, (Code PK 6102, Vector Laboratories, Burlingame, CA, EUA); 'VECTASTAIN ABC Elite Kit, (Code PK 6101, Vector Laboratories, Burlingame, CA, EUA); ${ }^{\text {d }} 0,1 \mathrm{~g}$ of bovine serum albumin (BSA) in $5 \mathrm{~mL}$ of phosphate buffered saline (PBS), incubated together with primary antibody; ${ }^{\mathrm{e}}$ Kit Easypath USA (code EP-USA, Erviegas, São Paulo, Brazil).

The positive controls for the reactions with the primary antibodies anti-P-gp anti-MRP1 were canine intestine, whereas canine testicles were used for the anti-GSTpi reaction. Canine mammary carcinoma specimens previously tested and with known p53 expression were employed as positive control in the reactions with the antibody anti-p53. As negative controls, the primary antibodies were switched by phosphate-buffered saline.

The evaluation of the immunostaining was accomplished by one or two examiners. Five fields per slice were randomly selected and in each 100 stained and non-stained neoplastic cells were computed with a micrometric reticulum (Nikon, Inc., Japan) at 400x magnification. Percentages of stained neoplastic cells relative to the total number of cells were determined. The specimens were considered positive for the P-gp, MRP1, GSTpi and p53 expression if they presented more than $10 \%$ of the cells stained, according to previous investigations (Miyoshi et al. 2002, Sueiro et al. 2004, Sokołowska et al. 2005, Yonemaru et al. 2007).

Statistical analysis. Fisher's exact test and Spearman's rank correlation coefficient were employed in the analysis of the results, with P-value $<0.05$ attaining a significant difference (Prisma 5.0 for Windows, GraphPad Software, San Diego California USA).

\section{P-gp expression}

\section{RESULTS}

The P-gp expression in the neoplastic cells was cytoplasmic, showing granular and diffuse aspect (Fig.1A). Staining of the mononuclear cell infiltrate was also observed (Fig.1B). The number and percentage of TVT1 and TVT2 positive specimens is given at Table 3. Minimum, maximum, interquartiles, and median of the percentage of stained neoplastic cells for the four immunohistochemistry techniques used in both experimental groups of this study are shown at Figure 2.

\section{MRP1 expression}

MRP1 expression was considered negative (less than $10 \%$ of cells stained) in all 14 TVT specimens analyzed (Table 3). In four specimens of the TVT1 group and in two specimens of the TVT2 group the granular and diffuse cytoplasmic expression of MRP1 was observed in less than $4 \%$ of the cells. Staining of the mononuclear cell infiltrate was observed in one specimen of the TVT1 group.

\section{GSTpi expression}

The isoenzyme GSTpi immunostaining pattern was mainly cytoplasmic, granular, and diffuse; however, there were some specimens that presented concurrent cytoplasmic and nuclear staining (Fig.3). Mononuclear cell infiltrate was observed in one specimen. The number and percentage of positive specimens for GSTpi from TVT1 and TVT2 is presented at Table 3 .

\section{Protein 553 expression}

The expression of protein p53 in the immunoreactive TVT specimens was mainly nuclear (Fig.4) with little cytoplasmic reaction. The number and percentage of positive specimens for p53 from TVT1 and TVT2 is shown at Table 3. 

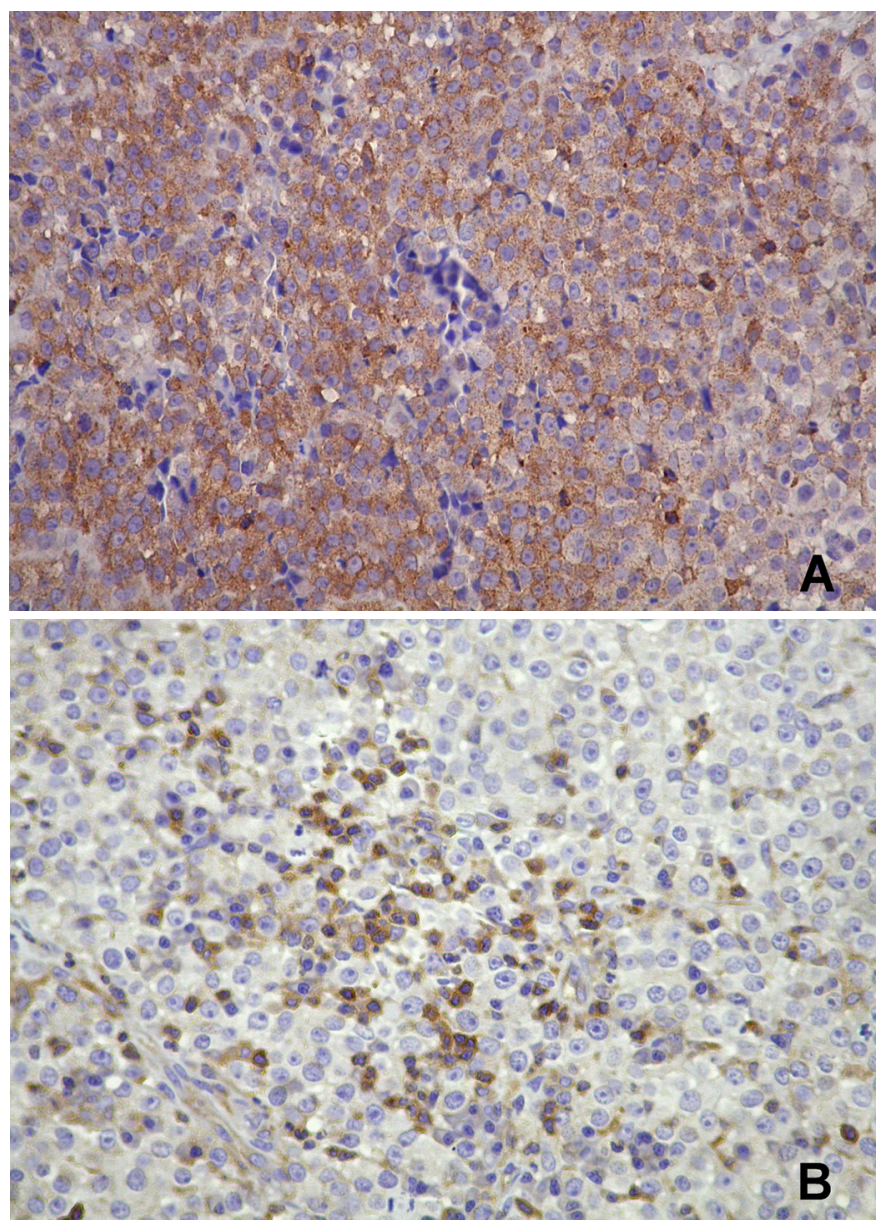

Fig.1. Canine TVT specimens from group TVT1 showing P-gp expression. 1A - shows brown color, granular and diffuse cytoplasmic staining in the neoplastic cells (x400). 1B - brown staining in the cytoplasm of the mononuclear inflammatory infiltrate and absence of staining in neoplastic cells . Immunohistochemical reaction (Streptavidin-biotin method), 400x.

Table 3. P-gp, MRP1, GSTpi and p53 expression in experimental groups by immunohistochemistry technique

\begin{tabular}{lcccc}
\hline Groups & P-gp & MRP1 & GSTpi & p53 \\
\hline TVT1 & $8 / 9$ & $0 / 9$ & $4 / 9$ & $2 / 9$ \\
& $(88.8 \%)$ & $(0 \%)$ & $(44.5 \%)$ & $(22.2 \%)$ \\
TVT2 & $4 / 5$ & $0 / 5$ & $4 / 5$ & $0 / 5$ \\
& $(80 \%)$ & $(0 \%)$ & $(80 \%)$ & $(0 \%)$ \\
TOTAL & $12 / 14$ & $0 / 14$ & $8 / 14$ & $2 / 14$ \\
& $(85.7 \%)$ & $(0 \%)$ & $(57.1 \%)$ & $(14.2 \%)$
\end{tabular}

\section{P-gp, MRP1, GSTpi and p53 expression}

The concurrent expression of the four markers, P-gp, MRP1, GSTpi, and p53, did not occur in any specimen. In TVT1 group, one specimen was positive for three of the markers (P-gp, GSTpi and p53); four were positive for two markers, one specimen for P-gp and GSTpi, two for P-gp and p53, and one for GSTpi and p53. Four specimens expressed only P-gp and one specimen expressed only GSTpi (Table 4). In experimental TVT2 group, three specimens expressed P-gp and GSTpi; one specimen expressed only P-gp, and one expressed only GSTpi (Table 5).

Spearman's rank correlation coefficient showed no correlation between the mean percentage of stained neoplastic
A

TVT1

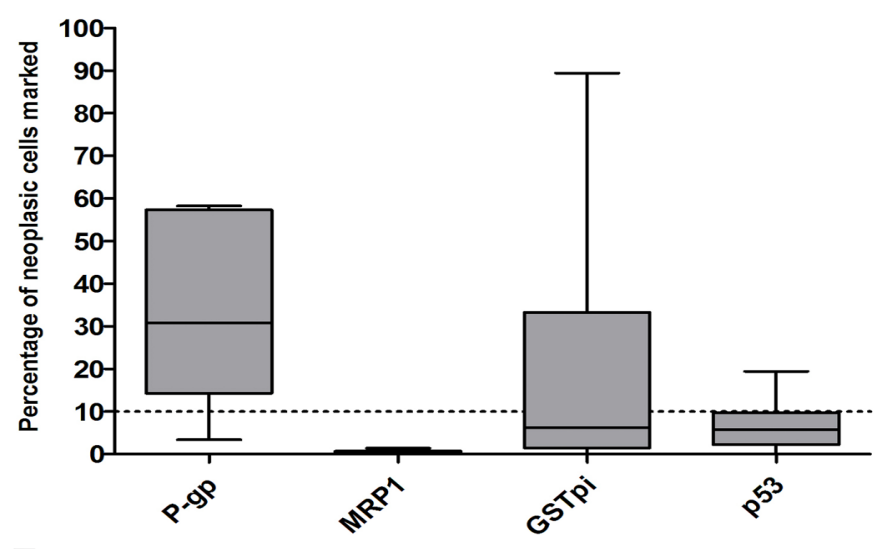

B

TVT2

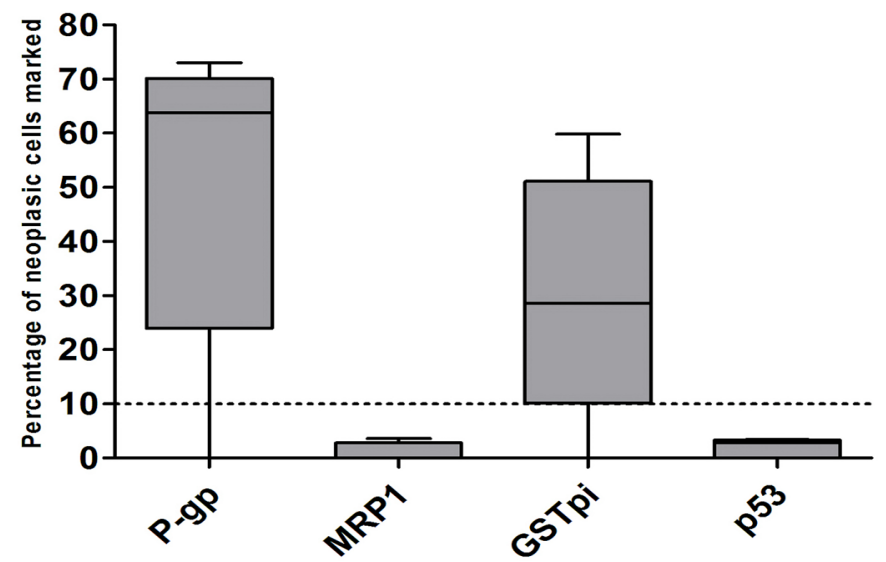

Fig.2. Graphical representation of the minimal and maximal percentages of neoplastic cells stained in groups TVT1 (A) and TVT2 (B) with the anti-Gp-P, MRP1, GSTpi and p53 antibodies. Continuous horizontal lines represent the median values. The boxes represent the interquartiles intervals $\left(25^{\text {th }}\right.$ to $75^{\text {th }}$ percentile). The sticks represent the minimal and maximal values of the percentage of stained neoplastic cells. The dashed horizontal line represent the threshold to define the specimen as positive for a given marker.

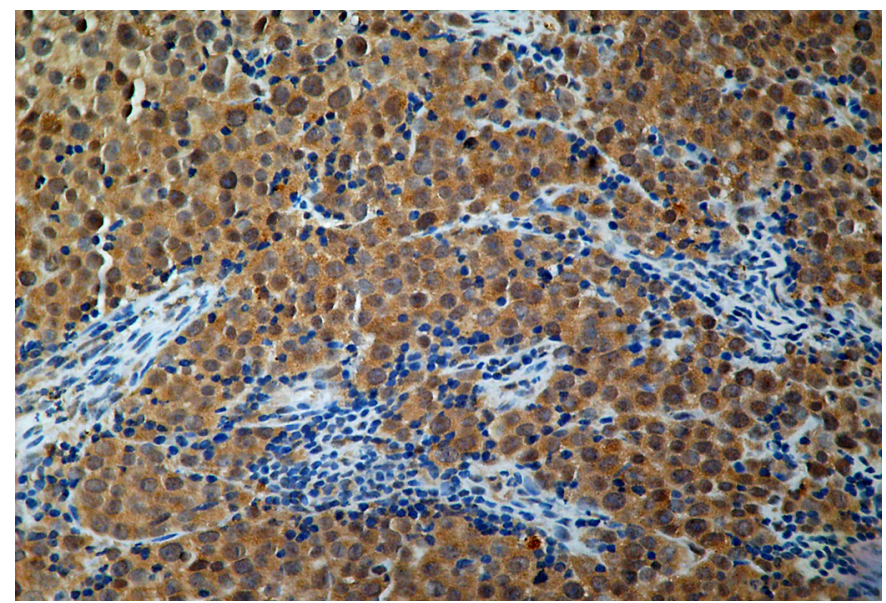

Fig.3. Canine TVT specimen from group TVT1 showing GSTpi expression. Brown color granular cytoplasmic stainings are shown. Immunohistochemical reaction (Streptavidin-biotin method), 400x. 


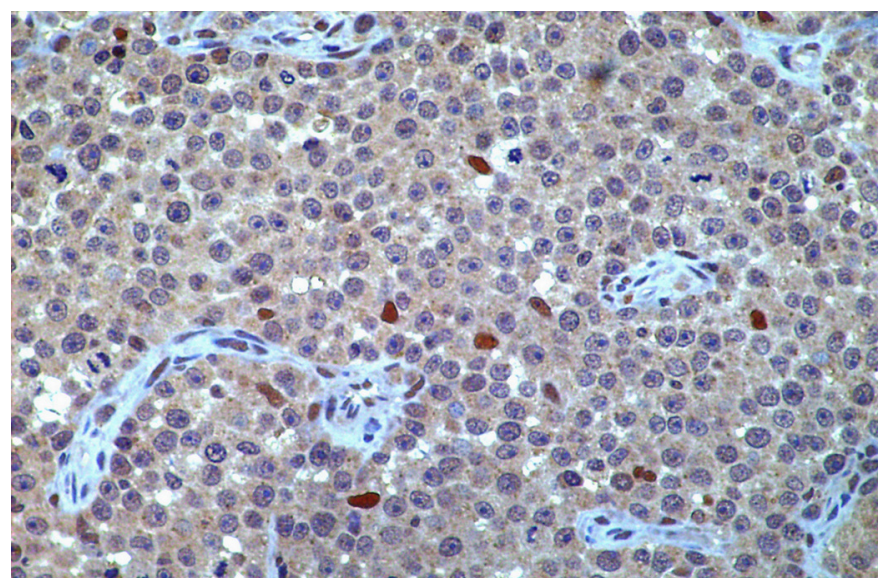

Fig.4. TVT specimen from group TVT1 showing p53 expression. Slight brown color nuclear staining in the neoplastic cells are visible (x400). Immunohistochemical reaction (Streptavidinbiotin method), 400x.

Table 4. P-gp, MRP1, GSTpi and p53 expression in specimens of TVT1 group

\begin{tabular}{|c|c|c|c|c|}
\hline P-gp & MRP1 & GSTpi & p53 & $\begin{array}{l}\text { Number of } \\
\text { Specimens }\end{array}$ \\
\hline
\end{tabular}

\begin{tabular}{lllll}
\hline+ & + & + & + & 0 \\
+ & + & + & - & 0 \\
+ & - & + & + & 1 \\
+ & + & - & + & 0 \\
+ & + & - & - & 0 \\
+ & - & + & - & 1 \\
+ & - & - & + & 2 \\
+ & - & - & - & 4 \\
- & + & + & + & 0 \\
- & + & + & - & 0 \\
- & + & - & + & 0 \\
- & + & - & - & 0 \\
- & - & + & + & 1 \\
- & - & + & - & 0 \\
- & - & - & + & 0
\end{tabular}

Table 5. P-gp, MRP1, GStpi and p53 expression in specimens of TVT2 group

\begin{tabular}{ccccc}
\hline P-gp & MRP1 & GSTpi & p53 & $\begin{array}{c}\text { Number of } \\
\text { specimens }\end{array}$ \\
\hline+ & + & + & + & 0 \\
+ & + & + & - & 0 \\
+ & - & + & + & 0 \\
+ & + & - & + & 0 \\
+ & + & - & - & 0 \\
+ & - & + & - & 3 \\
+ & - & - & + & 0 \\
+ & - & - & - & 1 \\
- & + & + & + & 0 \\
- & + & + & - & 0 \\
- & + & - & + & 0 \\
- & + & - & - & 0 \\
- & - & + & + & 0 \\
- & - & + & - & 0 \\
- & - & - & + & 0 \\
- & - & - & - &
\end{tabular}

cells for the several markers in either experimental group $(P>0.05)$.

\section{DISCUSSION}

Vincristine sulfate is the most effective drug to treat TVT (Calvert et al. 1982) with expected remission in over $90 \%$ of the cases. However, chemotherapy resistance is observed (Calvert et al. 1982, Rogers et al. 1998, Brandão et al. 2002) and resistance mechanisms are not completely understood. In humans, the multiple drug resistance is the main obstacle to the success in chemotherapy (Munoz et al. 2007) and supposedly also in canine neoplasms (Bergman et al. 1996, Lee et al. 1996, Mealey et al. 1998, Uozurmi et al. 2005).

As far as the authors concern, this is the first investigation that evaluates concurrent expressions of multidrug resistance P-gp, MRP1, p53 and enzyme GSTpi in canine TVT using immunohistochemistry. Recent studies described p53 (Santos et al. 2008, Moro et al. 2010) or P-gp (Gaspar et al. 2009) alone in canine TVT.

The four antibodies employed in this work were commercially developed against human antigens. Among them, the polyclonal anti-p53 antibody, clone CM1 (Novocastra Laboratories Ltd, Newcastle, UK) have already been successfully tested in canine neoplastic tissues (Sueiro et al. 2004, Keller et al. 2007; Moro et al. 2010). Similarly, the monoclonal anti-P-gp antibody, clone C494 (Signet Laboratories, Dedham, MA, USA) have been successfully employed in different canine neoplastic tissues (Ginn 1996, Petterino et al. 2006) and TVT (Gaspar et al. 2009). Until now, there were no known studies demonstrating cross-reactivity of the clones anti-MRP1 (Novocastra Laboratories Ltd, Newcastle, UK) and anti-GSTpi (Labvision Corporation, Fremont CA, USA) used in this research with canine tissues. Previous studies have used different commercial clones of the described antibodies and have shown successful staining of the corresponding proteins (Miyoshi et al. 2002) and enzymes (Rocha et al. 2000) in canine neoplastic tissues.

The diffuse cytoplasmic immunostaining pattern observed for the anti-P-gp antibody was consistent to what have been observed in other investigations with neoplastic tissues (Miyoshi et al. 2002, Petterino et al. 2006) and TVT (Gaspar et al. 2009). Nonetheless, the staining patterns seem to vary according to both the clone used and neoplastic tissue, being possible the staining of the plasma membrane and cytoplasm altogether (Ginn 1996).

In this study, a high percentage of positive specimens for P-gp has been observed. However, due to no significant difference observed between the number of positive specimens in TVT1 and TVT2 groups, this study cannot support that vincristine sulfate might induce P-gp expression.

In human tumors, the MRP1 expression is associated to multidrug resistance when P-gp was not involved, or it could be co-expressed with P-gp (Filipits et al. 2005; Ohsawa et al. 2005). In contrast to what is described for human tumors, it was not observed a significant expression of MRP1 in any of the groups evaluated herein. This protein is probably not associated to resistance prior to chemotherapy, as well as vincristine sulfate does not induce it in dogs with TVT. 
The observed cytoplasmic and nuclear GSTpi staining followed the same pattern described for human neoplastic tissues (Howells et al. 2004, Soh et al. 2005). In human beings this staining pattern has been related to prognosis (Howells et al. 2004, Soh et al. 2005) although controversy exists. While two studies relate the concurrent nuclear and cytoplasmic GSTpi expression to a decreased survival time and chemotherapy resistance (Soh et al. 2005), another study (Howells et al. 2004) has associated the same staining pattern to a more favorable fruition. In this study it was observed the concurrent staining of nucleus and cytoplasm although more data is necessary to correlate the GSTpi location to TVT and the prognosis of other neoplasms in dogs.

Regardless of the controversy on the GSTpi staining pattern, its expression in human tumors is related to a reduced survival time and to chemotherapy resistance (Ribrag et al. 2003, Arai et al. 2008). In dogs, though the GST concentrations seem to be higher in neoplastic tissues as compared to normal tissues (Kumaraguruparan et al. 2006), such association was not find in a study by Rocha et al. (2000). However, one must consider the small number of neoplasms studied and the limited attention given to the expression of GSTpi in canine neoplasm.

In this investigation, a higher number of GSTpi positive cases was found in group TVT2 (80\%) than in group TVT1 (44.5\%). Although not statistically significant due to the sample size, one could assume that vincristine sulfate could induce the expression of GSTpi in TVT.

The p53 staining pattern is nuclear since this is a very important cell cycle regulatory protein. However, staining patterns either nuclear, nuclear and cytoplasmatic, or only cytoplasmic have been observed with this antibody in canine TVT. Some reasons could be suggested, including a complex formation between the mutant p53 and the heat shock protein hsp72/73 (Purdie et al. 1991), the binding of the wild p53 to mdm2 (Tominaga et al. 1993), p53 inactivation through nuclear exclusion (Bosari et al. 1994), or the $\mathrm{C}$-terminal portion of the protein is present in the cytoplasm (Haga et al. 2001). Although these arguments are supported by literature, in this study only nuclear stained cells were considered positives.

Mutations in p53 are frequently observed in human neoplasms and some are associated to MDR (Luqmani 2005). The role of the mutated p53 is not yet elucidated in canine neoplasms. The p53 expression is related to a poor response to chemotherapy in lymphomas (Veldhoen et al. 1998), or to a worse prognosis in mammary neoplasms (Lee et al. 2004). In this work, a higher percentage of positive cases was expected for TVT2 group in comparison to TVT1, which did not occur. In fact, none of the specimens were considered positive in group TVT2, whereas only two were positive in TVT1. Interestingly, a higher p53 expression was observed in transplanted TVTs in regression stage than in progression and latency of the TVTs transplanted to dogs (Moro et al. 2010), in agreement to what was found by Santos et al. (2008). These authors described a direct relationship between p53 expression and apoptotic index in the TVT in regression stage. Also, they suggest that the p53 expression in the canine TVT may correspond to the wild type protein.

The MDR, either innate or acquired, interfere with the efficacy of many antineoplastic drugs. It is established through multiple mechanisms acting in either isolated or synergistically fashion (Gillet \& Gottesman 2010). In this study the expression of the four markers, P-gp, MRP1, GSTpi and p53, did not occur in all TVT specimens. Only one specimen in group TVT1 was positive for three markers. Still in this group, the expressions of P-gp and p53 in two specimens, P-gp and GSTpi in one specimen and GSTpi and p53 in one specimen were observed. However, in group TVT2 there were three specimens expressing P-gp and GSTpi exclusively. Researchers have observed that the identification of MRP1, as an important glutathione conjugates efflux pump, increases the possibility that MRP1 and GST might act synergistically in some chemotherapy cell resistance (Townsend \& Tew 2003). However, in this study, positive specimens for GSTpi and MRP1 were not observed.

Besides the staining of the neoplastic cells, inflammatory infiltrate cells were also stained with the anti-P-gp, MRP1 and GSTpi antibodies in some specimens, according to what is described by Yang et al. (1999) in human mammary tumors. Additionally, Johnstone et al. (2000) reported that blood cells with cytolytic activity present a higher P-gp expression, suggesting that this glycoprotein is involved with immunological functions, i. e., relative to cytotoxicity mediated by $\mathrm{CD}^{+}$and Natural Killer (NK) cells. For some researchers evidence exists that P-gp plays an important role in $\mathrm{CD}^{+}, \mathrm{CD}^{+}$, antigen-presenting cells and NK and, therefore participates in the immune modulation response (Pendse et al. 2003). It is also known that MRP1 presents a relevant function during the activation of Th1 murine cells (Prechtl et al. 2000). Specific assays to determine the subpopulations of cells and the proteins functions in inflammatory cells have not been conducted in this investigation.

\section{CONCLUSION}

The studied canine TVT expressed the four markers evaluated, although only P-gp and GSTpi were expressed in an intense way, mainly in cytoplasm and cytoplasm and nuclei, respectively. This occurred before chemotherapy as well as after the exposure to vincristine sulfate. Future studies are needed to demonstrate the function of these two markers in the development of MDR in canine TVT.

Acknowledgements.- To Fundação de Amparo a Pesquisa do Estado de São Paulo for funding this study (Process number 06/52527-9). To Pedro Paulo Vissoto Diniz, Marlos Gonçalves Sousa and Mônica Guimarães Campiteli for performing the statistical analysis of this study and for helping during the English version of this manuscript.

\section{REFERENCES}

Arai T., Miyoshi Y., Kim S.J., Akazawa K., Maruyama N., Taguchi T., Tamaki Y. \& Noguchi S. 2008. Association of GSTP1 expression with resistance to docetaxel and paclitaxel in human breast cancers. J. Cancer Surg. 34(7):734-738.

Bergman P.J. 2003. Mechanisms of anticancer drug resistance. Vet. Clin. North Am., Small Anim. Pract. 33(3):651-667. 
Bergman P.J., Ogilvie G.K. \& Powers B.E. 1996. Monoclonal antibody C219 immunohistochemistry against P-glycoprotein: sequential analysis and predictive ability in dogs with lymphoma. J. Vet. Intern. Med. 10(6):354359.

Bosari S., Viale G., Bossi P., Maggioni M., Coggi G., Murray J.J. \& Lee A.K. 1994. Cytoplasmic accumulation of p53 protein: an independent prognostic indicator in colorectal adenocarcinomas. J. Natl Cancer Inst. 86(9):81-687.

Brandão C.V.S., Borges A.G., Ranzani J.J.T., Rahal S.C., Teixeira C.R. \& Rocha N.S. 2002. Tumor venéreo transmissível: estudo retrospectivo de 127 casos (1998-2000). Revta Educ. Cont. Med. Vet. Zoot., CRMV-SP 5(1):2531.

Calvert C.A., Leifer C.E. \& MacEwen E.G. 1982. Vincristine for treatment of transmisible veneral tumor in the dog. J. Am. Vet. Med. Assoc. 181(2):163-164.

Cohen D. 1985. The transmissible venereal tumor: a unique result of the tumor progression. Adv. Cancer Res. 43:75-112.

Cole S.P., Bhardwaj G., Gerlach J.H., Mackie J.E., Grant C.E., Almquist K.C., Stewart A.J., Kurz E.U., Duncan A.M. \& Deeley R.G. 1992. Overexpression of a transporter gene in a multidrug-resistant human lung cancer cell line. Science 258(5088):1650-1654.

DiPietro A., Dayan G., Conseil G., Steinfels E., Krell T., Trompier D., Baubichon-Cortay H. \& Jault J.M. 1999. P-glycoprotein-mediated resistance to chemotherapy in cancer cells: using recombinant cytosolic domains to establish structure-function relationships. Braz. J. Med. Biol. Res. 32(8):925-939.

Gaspar L.F.J., Amaral A.S., Bassani-Silva S. \& Rocha N.S. 2009. Imunorreatividade à glicoproteína-p nos diferentes tipos citomorfológicos de tumor venéreo transmissível canino. Veterinária em Foco 6(2):140-146.

Gillet J.P. \& Gottesman M.M. 2010. Mechanisms of multidrug resistance in cancer. Meth. Mol. Biol. 596:47-76.

Ginn P.E. 1996. Immunohistochemical detection of P-glycoprotein in formalin-fixed and paraffin-embedded normal and neoplastic canine tissues. Vet. Pathol. 33(5):533-541.

Haga S., Nakayama M., Tatsumi K., Maeda M., Shunsuke I., Umesako S., Yamamoto H., Hilgers J. \& Sarkar N.H. 2001. Overexpression of the $p 53$ gene product in canine mammary tumors. Oncol. Rep. 8(6):215-1219.

Howells H.E., Dhar K.K., Hoban P.R., Jones P.W., Fryer A.A., Redman C.W. \& Strange R.C. 2004. Association between glutathione-S-transferase GSTP1 genotypes, GSTP1 over-expression, and outcome in epithelial ovarian cancer. Int. J. Gynecol. Cancer 14(2):242-250.

Johnstone R., Ruefli A. \& Smyth M.J. 2000. Multiplephysiological functions for multidrug transporter P-glycoprotein? Trends Biochem. Sci. 25(1):16.

Keller S.M., Schade B., Rickenbacher A.B., Brugnera E., Wergin M.C., Müller E.J., Suter M.M. \& Guscetti F. 2007. A comprehensive test system to identify suitable antibodies against p53 for immunohistochemical analysis of canine tissues. J. Comp. Pathol. 137(1):59-70.

Knapp D.W., Waters D.J. \& Schmidt B.R. 2000. Tumors of Urogenital System and Mammary Glands, p. 541-546. In: Ettinger S.J. \& Feldman E.C. (Eds), Textbook of Veterinary Internal Medicine: diseases of the dog and cat. $5^{\text {th }}$ ed. W.B. Saunders, Philadelphia.

Konstantinidou A.E., Korkolopoulou P. \& Patsouris E. 2002. Apoptotic mar kers for tumor recurrence: a minireview. Apoptosis 7(5):461-470.

Kumaraguruparan R., Subapriya R., Balachandran C., Manohar B.M., Thangadurai A. \& Nagini S. 2006. Xenobiotic-metabolizing enzymes in canine mammary tumors. Vet. Journal 172(2):364-368.

Lee C.H., Kim W.H., Lim J.H., Kang M.S., Kim D.Y. \& Kweon O.K. 2004. Mutation and overexpression of p53 as a prognostic factor in canine mammary tumors. J. Vet. Sci. 5(1):63-69.

Lee J.J., Hughes C.S., Fine R.L. \& Page R.L. 1996. Pgp expression in canine lymphoma: a relevant, intermediate model of multidrug resistance. Cancer 77:1892-1898.

Lorimier L.P. \& Fan T.M. 2007. Canine transmissible venereal tumor, p.799804. In: Withrow S.J. \& MacEwen E.G. (Eds), Small Animal Clinical Oncology. $4^{\text {th }}$ ed. W.B. Saunders, Philadelphia. 846p.
Luqmani Y.A. 2005. Mechanisms of drug resistance in cancer chemotherapy. Medical Principles and Practice 14:35-48.

MacEwen E.G. 2001. Transmissible venereal tumor, p.651-656. In: Withrow S.J., MacEwen E.G. (Eds), Small Animal Clinical Oncology. $3^{\text {rd }}$ ed. W.B. Saunders, Philadelphia. 718p.

Mealey K.L., Barhoumi R., Rogers K. \& Kochevar D.T. 1998. Doxorubicin induced expression of P-glycoprotein in a canine osteosarcoma cell line. Cancer Lett. 126(2):187-192.

Miyoshi N., Tojo E., Oishi A., Fujiki M., Misumi K., Sakamoto H., Kameyama K., Shimizu T. \& Yasuda N. 2002. Immunohistochemical detection of P-glycoprotein (PGP) and multidrug resistance-associated protein (MRP) in canine cutaneous mast cell tumors. J. Vet. Med. Sci. 64(6):531-533.

Moro J.V., Tinucci-Costa M., Silveira A.C.T., Gerardi D.G. \& Alessi A.C. 2010. Reactivity of p53 protein in canine transmissible venereal tumor. Arq. Bras. Med. Vet. Zootec. 62(2):318-323.

Munoz M., Henderson M., Haber M. \& Norris M. 2007. Role of the MRP1/ ABCC1 multidrug transporter protein in cancer. Life 59(12):752-757.

Ohsawa M., Ikura Y., Fukushima H., Shirai N., Sugama Y., Suekane T., Hirayama M., Hino M. \& Ueda M. 2005. Immunohistochemical expression of multidrug resistance proteins as a predictor of poor response to chemotherapy and prognosis in patients with nodal diffuse large B-cell lymphoma. Oncology 68:422-431.

Pendse S., Sayegh M.H. \& Frank M.H. 2003. P-glycoprotein--a novel therapeutic target for immunomodulation in clinical transplantation and autoimmunity? Curr. Drug Targets 4(6):469-476.

Petterino C., Rossetti E., Bertoncello D., Martini M., Zappulli V., Bargelloni L. \& Castagnaro M. 2006. Immunohistochemical detection of P-glycoprotein (clone 494) in canine mammary gland tumors. J. Vet. Med. 53(4):174-178.

Prechtl S., Roenllinghoff M., Scheper R., Cole S.P., Deeley R.G. \& Lohoff M. 2000. The multidrug resistance protein 1: a functionally important activation marker for murine Th1 cells. J. Immunol. 164(2):754-761.

Purdie C.A., O'Grady J., Piris J., Wyllie A.H. \& Bird C.C. 1991. p53 expression in colorectal tumors. Am. J. Pathol. 138(4):807-809.

Ribrag V., Koscielny S., Carpiu I., Cebotaru C., Vande Walle H., Talbot M., Fenaux P. \& Bosq J. 2003. Prognostic value of GST-pi expression in diffuse large B-cell lymphomas. Leukemia 17(5):972-977.

Rocha T.A., Mauldin G.N., Patnaik A.K. \& Bergman P.J. 2000. Prognostic factors in dogs with urinary bladder carcinoma. J. Vet. Intern. Med. 14(5):486-490.

Rogers K.S., Walker M.A. \& Dillon H.B. 1998. Transmissible veneral tumor: a retrospective study of 29 cases. J. Am. Anim. Hosp. Assoc. 34(6):463470.

Santos F.G.A., Vasconcelos A.C., Nunes J.E.S., Cassali G.D., Paixão T.A., Martins A.S., Silva S.S., Martins R.F. \& Moro M.L. 2008. Apoptosis in the transplanted canine transmissible venereal tumor during growth and regression phases. Arq. Bra. Med. Vet. Zootec. 60(3):607-612.

Soh Y., Goto S., Kitajima M., Moriyama S., Kotera K., Nakayama T., Nakajima H., Kondo T. \& Ishimaru T. 2005. Nuclear localization of glutathione S-transferase pi is an evaluation factor for drug resistance in gynaecological cancers. Clin. Oncol. 17(4):264-270.

Sokolowska J., Cywinska A. \& Malicka E. 2005. p53 expression in canine lymphoma. J. Vet. Med. 52(4):172-175.

Sueiro F.A.R., Alessi A.C. \& Vassallo J. 2004. Canine lymphomas: a morphological and immunohistochemical study of 55 cases, with observations on p53 immunoexpression. J. Comp. Pathol. 131(2/3):207213.

Thomas H. \& Coley H.M. 2003. Overcoming multidrug resistance in cancer: an update on the clinical strategy of inhibiting P-glycoprotein. Cancer Control 10(2):59-165.

Tinucci-Costa M. 2009. Tumor venéreo transmissível, p.539-556. In: Daleck C.R., Nardi A.B. \& Rodaski S. (Eds), Oncologia em Cães e Gatos. Roca, São Paulo. 846p.

Tominaga O., Hamelin R., Trouvat V., Salmon R.J., Lesec G., Thomas G. \& Remvikos Y. 1993. Frequently elevated content of immunochemically 
defined wild-type p53 protein in colorectal adenomas. Oncogene 8(10):2653-2658.

Townsend D.M. \& Tew K.D. 2003. The role glutathione-S-transferease in anti-cancer drug resistance. Oncogene 22(47):369-7375.

Uozurmi K., Nakaichi M., Yamamoto Y., Une S. \& Taura Y. 2005. Development of multidrug resistance in a canine lymphoma cell line. Res. Vet. Sci. 78(3):217-224.

Veldhoen N., Stewart J., Brown R. \& Milner J. 1998. Mutations of the p53 gene in canine lymphoma and evidence for germ line p53 mutations in the dog. Oncogene 16(2):249-255.

Yang X., Uziely B., Groshen S., Lukas J., Israel V., Russell C., Dunnington G., Formenti S., Muggia F. \& Press M.F. 1999. MDR1 gene expression in primary and advanced breast cancer. Lab. Invest. 79(3):271-280.

Yonemaru K., Sakai H., Marakami M., Kodama A., Mori T., Yanai T., Maruo K. \& Masegi T. 2007. The significance of $\mathrm{p} 53$ and retinoblastoma pathways in canine hemangiosarcoma. J. Vet. Med. Sci. 69(3):271-278. 